Diego Rotman

The Yiddish Stage as a Temporary Home 



\section{Diego Rotman}

\section{The Yiddish Stage}

as a Temporary

Home

Dzigan and Shumacher's Satirical Theater (1927-1980)

Translated from the Hebrew by Rebecca Wolpe

\section{DE GRUYTER}

OLDENBOURG MAGNES 
This book was published with the support of the Israel Science Foundation and the Kronhill Pletka Foundation.

This book is a translation from the Hebrew original:

Diego Rotman. Habama kebayit 'ara'i: Hate'ațron shel Dzigan ṿeShumacher (1927-1980). Jerusalem: Magnes, 2017.

ISBN 978-3-11-071742-6

e-ISBN (PDF) 978-3-11-071769-3

e-ISBN (EPUB) 978-3-11-071777-8

Library of Congress Control Number: 2021930352

\section{Bibliographic information published by the Deutsche Nationalbibliothek}

The Deutsche Nationalbibliothek lists this publication in the Deutsche Nationalbibliografie; detailed bibliographic data are available on the Internet at http://dnb.dnb.de.

(c) 2021 Walter de Gruyter GmbH, Berlin/Boston and The Hebrew University Magnes Press, Jerusalem

Cover illustration: “Dzigan and Shumacher 2017-2018” by Adi Kaplan and Shahar Carmel, oil pastel on paper, $24 \mathrm{~cm} \times 24 \mathrm{~cm}$.

Typesetting: Integra Software Services Pvt. Ltd.

Printing and binding: $\mathrm{CPI}$ books $\mathrm{GmbH}$, Leck

www.degruyter.com 